inOedia $\quad \begin{aligned} & \text { InMedia } \\ & \text { The French Journal of Media Studies }\end{aligned}$

7.2. $\mid 2019$

Documentary and Entertainment

\title{
Documenting and Popularising British nuclear power: Exploring science infotainment
}

Lucie de Carvalho

\section{(2) OpenEdition \\ 12 Journals}

\section{Electronic version}

URL: http://journals.openedition.org/inmedia/1607

DOI: 10.4000/inmedia.1607

ISSN: 2259-4728

\section{Publisher}

Center for Research on the English-Speaking World (CREW)

Printed version

Date of publication: 15 December 2019

\section{Electronic reference}

Lucie de Carvalho, "Documenting and Popularising British nuclear power: Exploring science

infotainment ", InMedia [Online], 7.2. | 2019, Online since 16 December 2019, connection on 26 January 2021. URL: http://journals.openedition.org/inmedia/1607 ; DOI: https://doi.org/10.4000/inmedia.1607

This text was automatically generated on 26 January 2021.

(C) InMedia 


\title{
Documenting and Popularising British nuclear power: Exploring science infotainment
}

\author{
Lucie de Carvalho
}

\section{Introduction}

1 When Stephen Hawking passed away on March 14, 2018, much of the tribute paid underscored his iconic popularising skills. With the likes of Richard Attenborough or Jeremy Vine, Hawking rose to the status of documentary voice and British national public treasure. He also helped build bridges between science and the British public both through books and documentaries. The latter in particular have held a place of pride in the popularising techniques regarding the sometimes-esoteric world of natural or experimental sciences. As a television sub-genre, documentaries are distinct from news-providing or fiction programmes but borrow elements from both. For Bill Nichols, "The appearance of documentary involves the combination of three preexisting elements--photographic realism, narrative structure, and modernist fragmentation-along with a new emphasis on the rhetoric of social persuasion." It means that a documentary is based on chronicling the "real" through images and sounds, mostly with an activist intent. Yet, this documentary "reality" differs from that of the newsreels since it is scripted and altered through the use of cinema techniques which endow the documentary with aesthetic depth. As Nichols's definition reveals, documentaries can be difficult to define due to their essentially "cross-[bred] formats," drawing from "the newsreel, street interview, current affairs programme, naturalist drama and cinema-vérité documentary." As such, documentaries tend to blur "established television viewing codes" 2 and emerge as a hybrid or "Janus-faced genre, at the same time evidence and artifice." ${ }^{3}$ Based on experimentation and innovation, science documentaries occupy a mediating space between scientific and popular cultures. 
2 Documentaries are a hybrid product in terms of genre, but also in terms of communication techniques. Science documentaries tend to borrow elements of entertainment in order to popularise complex and controversial content, and thus capture the interest of elusive and often jargon-adverse viewers. Nuclear power is a paragon of such a strategy as it is often depicted as "not very glamorous" and "lack[ing] in sexiness," being often lumped with "bleak, spit-curdling footage of mushroom clouds." ${ }^{4}$ Nuclear power is also a compelling case of controversial science, characterised by a lack of scientific consensus and transparency. Journalists, scientists, and the public have had to grapple with its fundamental scientific uncertainty. ${ }^{5}$ As such, nuclear power stands out as a prime candidate for popularising and newsworthy narratives.

3 Popularisation tightly links modern documentaries with another hybrid genre: infotainment. The portmanteau word 'infotainment' emerged in academic literature in the early 1990s to label the process of combining genres - mostly news, politics, and popular culture. This new term was mostly used to refer to the growing popularity of another TV format: talk shows. They illustrate this rising intertwining of newsproviding and entertainment, paired with a blurring of the lines between two traditionally separate media genres. ${ }^{6}$

4 This growing clout of infotainment over popular media has raised concerns among analysts and researchers. While some argue that by mixing information and entertainment, such news programming tends to put too much emphasis on sensationalism, personalities, and spectacle, others believe that it gives credence to what Bourdieu called "cultural fast-food" or "pre-digested or pre-thought cultural sustenance."7 Many scholars approach infotainment as symptomatic of an erosion of democratic values. ${ }^{8}$ Ratings-driven competition enhances the fragmentation of the media ecosystem, which is often identified as the prime driver for the strong popularity of such entertainment-based communication practices. ${ }^{9}$

5 Conversely, other researchers have called for transcending such a normative approach, to underline how infotainment may also stand for a valuable epistemological tool to explore recent media dynamics ${ }^{10}$ and might be discussed as a new stage in modern journalism history. ${ }^{11}$ The question that arises here is whether such comments can also be applied to infotainment in science TV documentaries. Although widely researched in political programmes and current affairs content, infotainment remains a fairly recent phenomenon in television documentaries. ${ }^{12}$

6 This study will focus on post-2010, British-made and British-centred television documentary films on nuclear power, broadcast on mainstream television. These criteria were determined for the sake of obtaining a coherent comparison. Only two BBC sources were found. The first documentary is entitled Britain's Nuclear Secrets: Inside Sellafield directed by Tim Usborne ${ }^{13}$ and was first aired on 10 August 2015 as part of the "BBC 4 Goes Nuclear" season. This documentary attracted substantial acclaim for its "simplicity" and "scientific rigour" and was even awarded the Physics Prize by the European Physical Society at the 2016 European Science TV and New Media Festival. ${ }^{14}$ Britain's Nuclear Secrets: Inside Sellafield walks the viewers through 37 years of the atomic age, especially focussing on Sellafield's current reprocessing mission. The second documentary is part of the BBC1 Panorama documentary series and is entitled Sellafield's Nuclear Safety Failings. This documentary was directed by Richard Cookson, presented by journalist Richard Bilton and was first aired on 5 September 2016. 
7 Interestingly enough, both documentaries focus on the same topic: Britain's oldest and most developed nuclear complex, Sellafield. The Sellafield site is the heart of the country's nuclear fuel reprocessing and decommissioning activities. As it was established in Cumbria in the mid-1950s, Sellafield is the oldest nuclear site in Britain today. ${ }^{15}$ Sellafield crystallises current concerns over the nuclear-induced environmental and health consequences. This was mainly due to its dark connections with the country's atomic programmes, the controversial reprocessing activities it has been harbouring, and several contamination incidents that have occurred there since the 1950s. Beyond focussing on the same topic, both aim at making a case for popularising a specific political message, while relying on journalistic and fictional editing and staging techniques. Finally, both shows were given prime time airing slots on the $\mathrm{BBC}$ and obtained high viewing-ratings. In terms of context, both shows were commissioned and aired in the backdrop of what came to be known as the Nuclear Renaissance.

8 Indeed, the advent of a paradigmatic transition from the post-industrial to the ecological age has breathed new life into nuclear power industries across the world in the late 2000s. Accompanied by an upsurge in political, industrial, and academic interests, nuclear power's relevance was reasserted in the transition towards a lowcarbon future and the UK joined the fray of this nuclear revival in 2008. Despite its lowcarbon footprint, the industry was still plagued by its controversial past and dangerous waste legacy. The focus of popular attention and environmentalist groups remained set on the question of decommissioning and management of nuclear waste. Consequently, the nuclear project was still under heavy political and media fire despite the government's best efforts to 'clear' or 'green' the industry. In July 2013, The Guardian even published an article entitled "The Nuclear Renaissance was just a fairy-tale," arguing that nothing justified launching a new nuclear programme. ${ }^{16}$ In the early 2010 s, the new nuclear build project could still take two very radically different paths: it could either follow course or be shelved. ${ }^{17}$

9 The purpose of this article is thus to address the impact of context on the content of these two documentaries. This idea will also be used to explore the relationship between providing scientific information and entertainment in television science documentaries, in order to determine how the use of entertainment as a set of communication techniques impacts the format and content of science documentaries. In other words, the ultimate purpose will be to discuss how infotainment informs and influences the policies behind exposing viewers to scientific content. The idea will be to determine whether infotainment is an instrument, a set of rhetorical devices meant to ease the programme's education mission, or an ultimate goal in this popularisation process. Analysing science documentaries will finally determine whether the context of the ecological age influences the popularising approach that has so far characterised science documentary - a sub-genre that is deeply anchored in the BBC documentary tradition. 


\section{The BBC documentary tradition}

\section{Science Documentaries on British Television}

10 The first documentary is considered by some to be the Lumières Brothers (Workers Leaving the Lumière Factory, 1895). The birth of the documentary tradition therefore coincided with the advent of cinema, thus establishing a tight bond between the two. In Britain, the documentary tradition blossomed under state protection: it was granted institutional recognition as early as the 1920s, as John Grierson, one of the very first British documentary-filmmakers, convinced "the British government to establish a film-making unit within the Empire Marketing Board, an agency charged with the circulation of food products and the promotion of empire. "Thus it was on his watch that documentary film practice reached maturity." ${ }^{18}$ In a valuable account of the postwar history of science documentaries on British public channels, science historian Gouyon explored the various key stages in the blossoming of this TV genre. ${ }^{19} \mathrm{He}$ argued that science documentary gained particular prominence thanks to the enduring success of the famous 1,200-long episode Horizon programme, one of the most successful science TV documentary series, which was first aired on BBC in 1968.

11 At first fairly sympathetic to the prevailing positivist ethos which characterised the 1950s and 60s, British science documentaries "took a more critical turn" from the 1970s onward. ${ }^{20}$ The pace quickened in the subsequent two decades, as the explosion of television capabilities accompanied and accelerated a political activist turn in science documentary material and the expansion of investigative journalism. ${ }^{21}$ The relationship between political choices and controversial scientific innovation then became a prime angle of choice for scientific inquiries. Science journalists were less likely to offer supportive narratives of scientific endeavours but would more regularly engage in critical comments. ${ }^{22}$ Windscale the Nuclear Laundry, aired in November 1983 on Yorkshire Television, for instance, tackled the contentious question of health hazards induced by nuclear activity at Windscale/Sellafield. In 1992, director Adam Curtis released a 6episode Pandora's Box Series aired on BBC2. This documentary focussed on technocratic decision-making in British nuclear politics and garnered critical acclaim as it was awarded a BAFTA for Best Factual Series in 1993. The two documentaries illustrated these more critical attempts at debunking the hegemonic discourses on nuclear safety and public trust in nuclear technologies in the wake of the 1979 Three Mile Island, and 1986 Chernobyl accidents for Curtis's documentary.

\section{The Role of the BBC in bolstering science popularisation}

Very early on, British scientific bodies were adamant that some media space be left for public science in order to "persuade the public or influential sectors thereof, that science [...] is worthy of receiving public attention, encouragement and financing." ${ }^{23}$ Here British science historian Frank Turner outlined what would later become a statesponsored "public understanding of science." Such state endorsement would firmly anchor science popularisation in the British public media tradition. ${ }^{24}$ Television science documentaries became the prime vehicle for this two-pronged mission of entertaining and informing via a popular media. ${ }^{25}$ The $\mathrm{BBC}$ in particular took on this role of offering such popularising content to their viewers. ${ }^{26}$ This even became part of its primary functions, as outlined in its Royal Charter: "The Mission of the BBC is to act in the 
public interest, serving all audiences through the provision of impartial, high-quality and distinctive output and services which inform, educate and entertain." ${ }^{27}$

Historian Tony Shaw therefore argued that "the BBC soon established a solid reputation for educational programming," while simultaneously claiming a "reputation for independence, impartiality and accuracy." ${ }^{28}$ Its unique status as a strong national media broadcaster enabled the company to strengthen its extended domestic and international reach. Even today, the BBC remains Britain's prime public service broadcaster, leading the sector by controlling $31.57 \%$ of audience share, before ITV and Channel $4 .{ }^{29}$ More importantly, science documentaries remain today a cornerstone of the channel's identity. In April 2011 a YouGov survey asked the public which programmes should have their budget reduced. It revealed that the respondents were less supportive of cutting the budget allotted to documentaries as $74 \%$ - the highest rate - deemed that reducing the documentary budget would be unacceptable. These results reflect the British public's continual strong appetite for science programmes. Overall, such an enduring success reveals how BBC programming has forged a solid tradition of providing science documentary based on popularisation which has ensured a positive reception among their viewers. As Fahy demonstrated in his analysis of the BBC popularising series The Ascent of Man, "science flowed through popular culture" as "television allowed scientists to speak to vast numbers of citizens." ${ }^{30}$ In other words, the BBC's popularising approach was instrumental in allowing science outside the research labs.

Our analysis will now show that the two documentaries studied embrace the BBC's tradition of offering credible and educational content: their scientific credibility and popular appeal potential turn out to be supported by the choice of presenters on the one hand, and the use of orthodox popularising techniques on the other. Yet, it also appears that entertainment plays a critical part in modernising this popularising objective.

\section{Entertaining to educate: when infotainment blends with popularisation}

\section{Asserting the legitimacy of the presenters}

15 One of the fundamental premises to enter a popularisation contract with TV viewers is to establish the fundamental legitimacy of the host or presenter. The two documentaries under study engage in two different legitimising processes or strategies regarding their hosts. Inside Sellafield is presented by Jim Al-Khalili, a Professor of Theoretical Physics at the University of Surrey, where he holds the position of Chair in the Public Engagement in Science set up especially for his intent. When the documentary was shot and aired, Al-Khalili was also the head of the British Humanist Association (2013-2016). Beside these scientific credentials, he is a well-known BBC figure, having appeared on many a science show, and weekly presenting the Life Scientific on BBC Radio 4. In his own words, Jim Al-Khalili is both "an academic physicist" and "a public scientist," a "research scientist" and a "communicator" 31 - His expertise has often been acknowledged in British parliamentary debates on science questions. In other words, his binary status as a physicist keen on communicating and popularising science credits the programme with respectability and credibility. The 
professor embodies the "scientific elite" of "celebrity scientists." ${ }^{32}$ While his professional status is firmly anchored in the British Science Establishment, his academic status allows him to distance himself from the state-run nuclear actors, such as the National Nuclear Laboratory - where he nonetheless trained in the past. Finally, he also depicts himself as a member of the public eager to know more about Sellafield activities in the opening shots of the documentary. In sum, he assumes a three-faced persona, which aims at ensuring the viewers that he will not confuse personal or national interest with government interest. In the documentary, staging and props support his ambition: he is thus seen switching personas by switching 'costumes,' changing from his regular clothes (interested citizen), to a lab coat (scientist) and then protective gear (site guide), as depicted in the following screenshots:

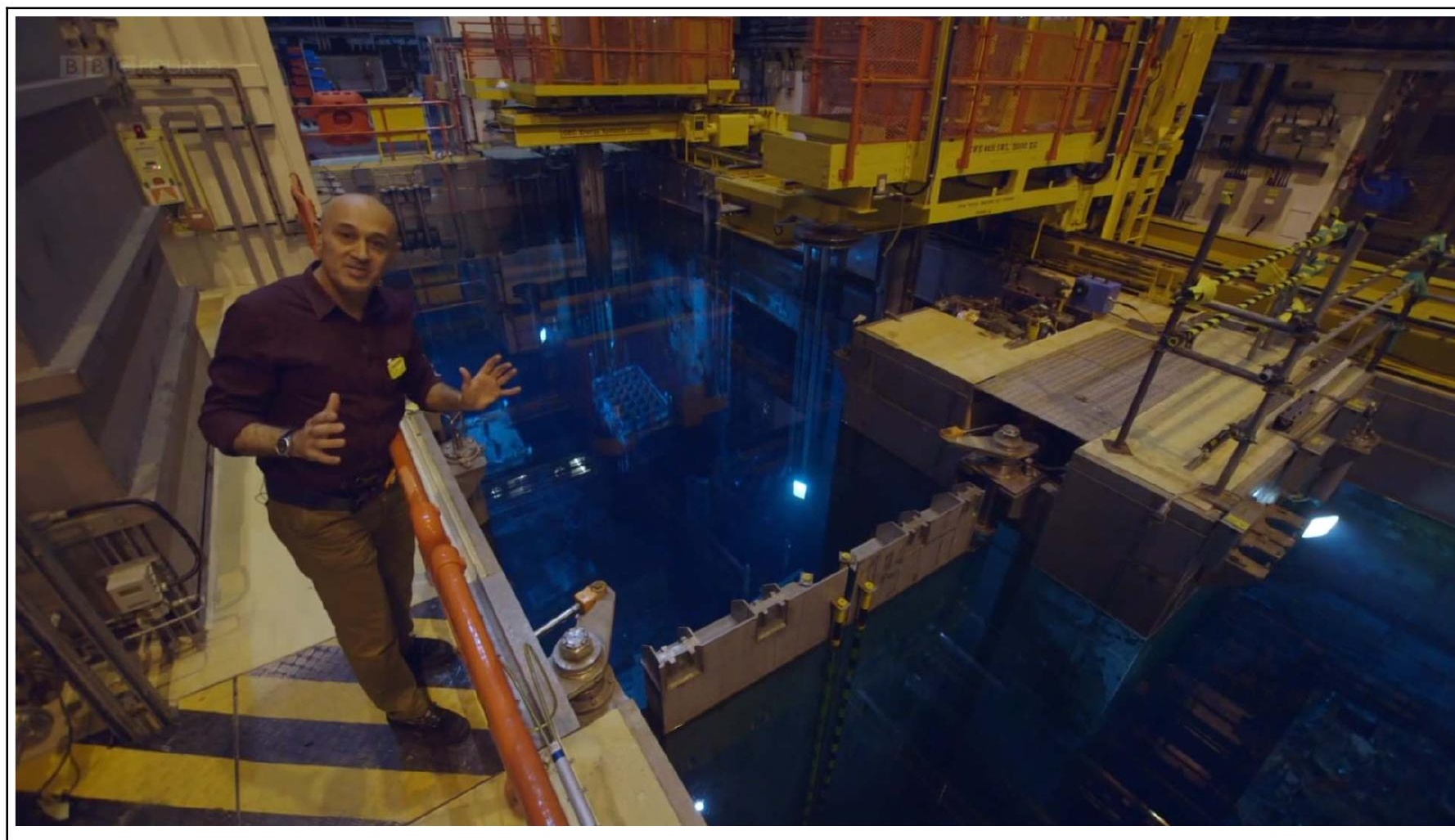

Doc 1. Screen captures (8:52, 21:36, 43:29): Al-Khalili's three personas in Inside Sellafield.

Far from channelling potentially state-framed discourses, Al-Khalili contends that the purpose of science documentaries is two-fold: to arouse lay people's interest in nuclear science, while simultaneously explaining and making potentially complex phenomena easy to understand by the general public. In that sense, he also defines himself as an "explainer" in a self-essentialising process - being even "the ideal science explainer of the age" ${ }^{33}$ for some - winning the Royal Society Michael Faraday Prize for Science Communication. For some viewers, the contract seems to be fulfilled: "Al-Khalili explains everything [...] with his usual clarity, never once patting the collective head or aiming clear over the top of it. In short he's the kind of reassuring presence you would want around in the event of a nuclear disaster." ${ }^{34}$

The second documentary has quite a different lead. The figure of the 'investigator' is opposed to that of the Al-Khalili's 'populiser.' Here, the documentary's omniscient 
narrator and host is journalist Richard Bilton. He takes on the role of the watchdog investigator, whose credentials are established through his 25-year experience in broadcast journalism as $\mathrm{BBC}$ environmental correspondent. All in all, the persona assumed by the documentary host is a key element in granting legitimacy and credibility to the popularising and educating mission they embark on.

\section{Providing science edutainment to produce "enriched" viewers} fundamental challenge beguiling science popularisers arises: how to explain and represent complex scientific processes or phenomena, especially when those processes are invisible like radioactivity, radiation or nuclear fission? Both documentaries resort to fairly traditional mechanisms, which blend education with entertainment. As a Guardian critic noted: "to the relief of science idiots like myself, the first half of Inside Sellafield is given to Jim saying things like 'But what is nuclear energy?' while walking around enormous rooms containing vast, sterile equipment." 39 Indeed, in both documentaries, various questions are raised: what is a nuclear reaction? What is radiation? What does half-life mean? How is waste reprocessed? Metaphors prove particularly useful in answering those questions, since they allow the audience to easily picture the meaning through mundane or familiar parallels that tend to subdue the unpalatable scientific academese. Hartwell has suggested that metaphors and analogies are both the basis of scientific discovery and a fundamental by-product of science communication which commands viewers' perception of the unknown. ${ }^{40}$

For instance, Al-Khalili explains atom-splitting and a nuclear chain reaction by dropping a ping-pong ball in a box with 120 mousetraps, each loaded with another ping-pong ball. To materialise the impact of radiation, he then puts a green plant in a radiation accelerator. To explain the difference between the three forms of radioactivity, He uses a three-little-pig-like approach by demonstrating how natural radioactivity from a mineral naturally rises step-by-step. He first shows what alpha radiation is and how a thin sheet of paper can stop it. Then he highlights how beta radiations are more penetrating, this time blocked by a sheet of aluminium. Finally, he presents the gamma particles, much more dangerous, only to be contained by sheets of lead. The professor also engages in a live demonstration of how to split the atom. Here the scientific experiment is showcased as a sensational performance, reminiscent of the 
early stages of experimental science. ${ }^{41}$ In the programme presentation on the $\mathrm{BBC}$ website, director Tim Usborne emphasises how unprecedented this was:

To help television audiences understand the story we were attempting to tell in Britain's Nuclear Secrets: Inside Sellafield, we needed to recreate Otto Hahn's famous atom-splitting nuclear fission experiment from 1938. As we researched the complexities of performing the experiment we were struck by a sobering thought: as far as we could tell, no one had ever performed this experiment for TV before. And for good reason! ${ }^{42}$

A host of other "infotainment" techniques are also used to make the educative content more appealing to lay people in the Panorama programme. These techniques range from the use of computerised/game-style graphic modelling to visualise the layout of the site, to highlighting specific words or phrases from otherwise long written reports. Finally, Al-Khalili occasionally indulges in humorous and self-deprecating comments meant to play down the dangerous character of reprocessing activities. Overall, edutainment means to make science more visibly-approachable to the general public through entertainment techniques. ${ }^{43}$ Such an approach is not a new phenomenon as many scholars have identified documentary makers' performative strategy based on staging experiments and story-telling rhetorical devices. Such techniques correspond to traditional techniques used in infotainment-style science journalism. ${ }^{44}$

Yet the use of these entertainment techniques strengthens the directors' personal understanding of what matters and what needs to be understood by the viewers. As scientist Jalees Rehman bemoaned in 2013, if these techniques are useful to "capture the imagination of the intended audience," they are also coupled with what he calls "perfunctory comments" which fail to offer a nuanced view of the limits of the science narratives displayed. ${ }^{45}$ The overall intent is therefore not only to educate the public but also to expose them to a very personal set of scientific "truths." ${ }^{46}$

\section{Edutainment in service of "edifiers"}

The second other fundamental premise of documentaries as a genre is the notion of showing what directors put forth as their reality. Both documentaries' directors thus pledged to "speak the truth" about nuclear activities in Sellafield and address its controversial past. In the opening scenes of Inside Sellafield, Al-Khalili stresses that "he's heard the stories," and that he intends to "discover the real story" of Sellafield, thereby separating the folklore from the reality. The use of stock footage partakes in this will of presenting what happened as accurately as possible. This premise is predicated on the "notion that what you are seeing on screen is somehow a direct representation of what happened in the past." ${ }^{47}$ Thus, both documentaries endeavour to "consider the nuclear age from all sides - its ground-breaking opportunities as well as its terrifying dangers," as BBC channel Four's editor Cassian Harrison claimed.

Yet, when it comes to dealing with such a socially controversial object as nuclear power, ${ }^{48}$ establishing a set of truths cannot but serve an agenda, either set to legitimize and promote or criticize and confront set ideas. Uncertainty is often downplayed in media analysis of controversial science. ${ }^{49}$ Interestingly enough, the two documentaries analysed constitute an example of each set of diverging opinions about nuclear power, as Inside Sellafield concludes on a note of support for the nuclear venture following the official political stance, while the Panorama programme voices a stark piece of criticism of Sellafield as a form of counter-hegemonic discourse. Inside sellafield 
nonetheless tries to deflate potential criticism that would undermine its credibility by denying any state meddling in the content of the film. Indeed, Al-Khalili appears wary of such a potential limitation:

I made it clear from the outset, I would not act as the nuclear industry's mouthpiece, but instead wanted to tell the story of our nuclear past, warts and all, and to give an honest appraisal of how far the industry has come since then. I am not a journalist; nor am I part of any politics lobby. Even as a scientist, I have no vested interest in whether Britain has a nuclear future or not. Whether I say good or bad things about nuclear power has no bearing on my research funding. ${ }^{50}$

The Panorama programme has a different take on the truth-seeking contract. The documentary director builds up a fiercer indictment case against the Sellafield management served by several infotainment techniques. More specifically, the Panorama programme aims to denounce not reprocessing per se, but the poor management of the sites and chronic under-investment which would have left the facilities to lapse into dangerous decay.

To pursue their truth-seeking and edifying agenda, both documentaries resort to sensationalist openers, such as the several unnerving cases of contamination and nearcatastrophic incidents which have plagued the past reputation of the site. This use of attention-grabbing dramatization processes results in reinforcing this polarisation of arguments through a simplification of the situation induced by popularisation and the documentary format. As it questions the state's and industry's official narratives, the Panorama programme relies more forcefully on sensationalism.

For instance, one of the compelling pieces of evidence used to expose poor management practices is the alleged fact that highly-radioactive materials are still kept in simple plastic bottles in the Sellafield laboratories. When confronted with the claim, the interviewed site manager admitted that it had indeed happened in the past, but that now it is a bygone practice. To investigate this potential security hazard, Cookson chooses to re-enact critical scenes to trigger the viewers' anxiety. Staging, introduces subjectivity and performance, thereby blurring the frontier between fact and fiction. The following screenshot illustrates this staging choice. The contrast between the operative's highly-protective gear and the basic plastic recipient said to contain highlytoxic materials somehow aims at replicating the contrast between the industry's reassuring communication discourses and its alleged practices. 


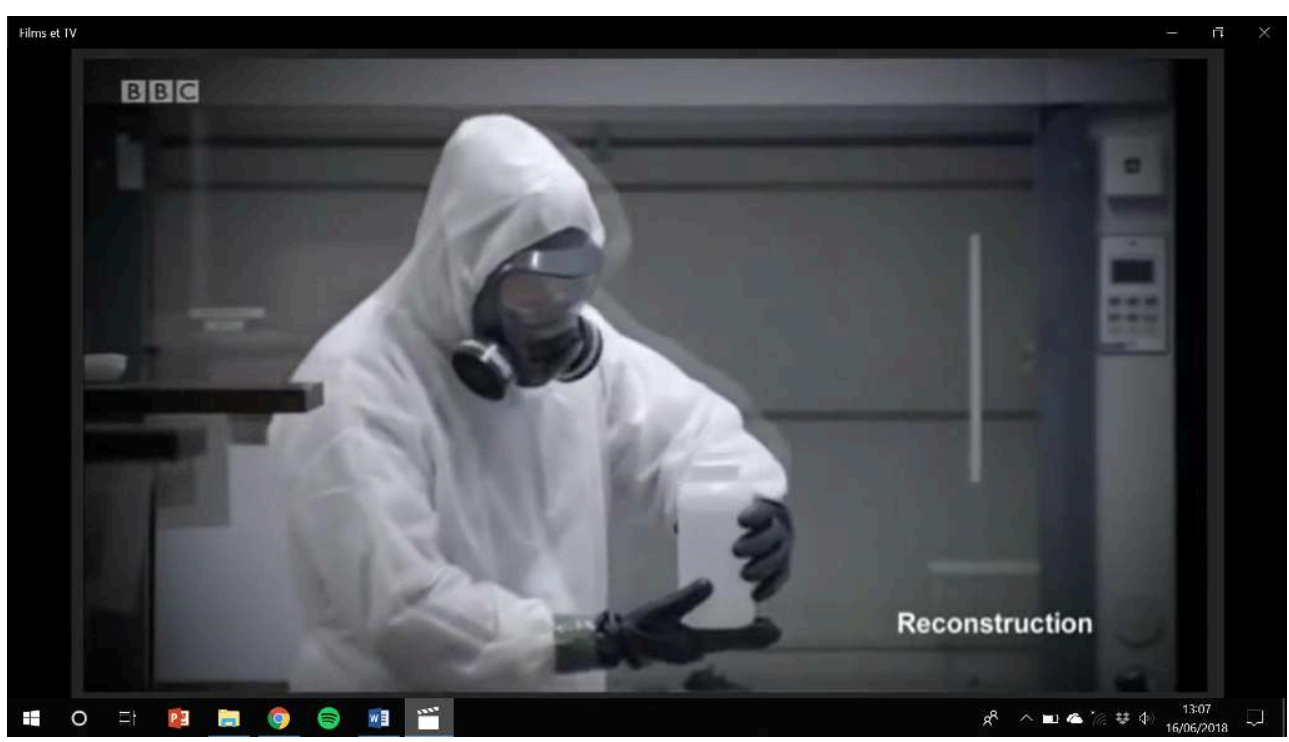

Doc 2. Screenshot, Sellafield operative handling highly-dangerous material, Panorama Programme $(7: 00)$.

In this case openly showcasing or staging reality is favoured at the expense of accuracy and authenticity, although the director used the forensic term 'reconstruction' over 'reenactment.'

The whole narrative used in the Panorama programme follows along the same lines, as exaggeration, simplification, and provocation prevail over accuracy. Documentary host Bilton uses several approximate figures. There are at first "a thousand" degraded plastic bottles storing uranium and plutonium; two minutes later, the figure soars to "two thousand plastic bottles." The sums of money injected in unsuccessful restoration projects undergo a similar treatment. Echoing Robert McKee's approach to storytelling, what seemingly matters more is the impact these images would have on the viewers than the message they are expected to get across. ${ }^{51}$ Those staging techniques deal a severe blow to the official industry narrative which ensures that the site meets excellent safety standards on which the whole popular trust in the industry rests. In other words, sensationalist dramatization and story-telling here aim at strongly undermining the site's safety culture through a subjective rendering of its reality.

In brief and particularly in the case of the Panorama programme, edutainment methods further erode the distinction between documentaries and fictitious renditions of the events, somehow returning to a more assumed modalised truth. Acclaimed British filmmaker Peter Kosminsky thus argued that "there's nothing inherently objective about documentaries. Every time someone chooses a particular section of an interview and juxtaposes it with a particular piece of music, they are steering the audience. ${ }^{\prime 52}$ In that, sense edutainment on the controversial topic of nuclear power goes beyond its original translation purpose of explaining things to the public. It also works as an edifying process creating new knowledge through their very specific mode of inquiry. Tensions are thus created between educating, truth-seeking and personal interpretation on public channels, taking advantage of the fact that documentaries are "perceived" by viewers as objective information. ${ }^{53}$ In other words, edifying is a fundamental condition not only to guarantee knowledgesharing for its own sake, but also to offer citizen-viewers the analytical tools necessary to make enlightened and qualified decisions. Yet using dramatizing devices for edifying 
purposes also leads to some contradictory consequences on the way nuclear power is represented on British TV screens. Instead of demystifying nuclear power, these programmes actually tend to reactivate what could be called the scientific sublime.

\section{Reactivating the scientific sublime: confronting viewers with the nuclear power myth}

33 Although edutainment is meant to debunk the mystique surrounding nuclear power and its elusiveness to simplify its workings, to make them understandable and approachable, documenting nuclear power activities is no mundane venture. It allows one to explore one of the most mysterious scientific areas, quantum physics and atom science. Ever since the early years of the atomic age, western cultures have fallen prey to a "powerful infatuation with the atom," construed as a key fascinating element in post-war mindset and culture. ${ }^{54}$ Nuclear power has suffused popular culture while simultaneously remaining a mysterious activity that only a handful of individuals can access - let alone understand. This ambiguous tension between proximity and distance is perceptible in these documentaries on the nuclear venture. It indeed appears that the use of cinematic means of representation and entertainment ingredients leads the directors to reactivate some elements of popular fascination or myth-forging for the mastery of the atom, which remains one of the most sophisticated and mysterious achievements in the history of scientific advancement.

\section{Sensationalising the esoteric nature of nuclear power}

Both documentaries claim their relevance by featuring a content never before shown on television as one of their key selling points: access to Sellafield. Accessing the Sellafield site indeed, represents quite an unprecedent achievement for a TV documentary crew, since nuclear sites have traditionally been - metaphorically and physically - fortified away from public scrutiny and shrouded in mystery for national security reasons. As Hogg underscores:

Official narratives, emerging from institutions of the nuclear state, shaped public understandings of nuclear science and nuclear Britain. This allowed the nuclear industry to become more easily institutionally embedded in British life, often without the possibility of public scrutiny of how the process happened, and why and how it continued to happen. ${ }^{55}$

He thus highlights how nuclear activities remained invisible while being at the same time an inescapable facet of modern political and scientific culture. This secretive quality of nuclear activity is here often stressed by both presenters as a regular reminder of how controversial but also restricted a zone Sellafield is. Providing documentary images - or visual reality/ materiality - of inside the plant constitutes quite an astonishing achievement. In both cases, it seems that the scenes from the site are more interesting than the voice-over, just like "how something got said came to matter as much or more than what got said." ${ }^{16}$ Many newspaper articles thus insist on how "cameras are being allowed behind the scenes_at the Sellafield nuclear power plant." 57 The presenter Jim Al-Khalili himself, underscored how making this documentary was "a once-in-a-lifetime opportunity" to gain "unprecedented access to some of the country's most secret buildings." Tim Usborne and Al-Khalili had to go 
through a two-year paperwork process to secure access to the site and be allowed to film inside the facilities. Besides, filming had to be approved not only by the nuclear industry (Nuclear Decommissioning Authority), but also by the British Home Office and Government. In some shots, some elements are even blurred or edited out. The Panorama documentary also claims unprecedent quality by showcasing the transgressive use of leaked confidential documents, although the crew had not been granted official access to the premises.

Through either authorised entry or trespassing, this idea of physically crossing into this scientific sanctuary is reinforced and dramatized by the camera work. Both documentaries opted for a similar initial approach by starting off with a bird's eye view of the nuclear complex, thus transcending the physical security barriers on the ground. Here again, the camera and images stand as an interface, as theorised by Latour and Winston, ${ }^{58}$ which spurs a feeling of excitement and heightened expectations coupled with 'the feeling of being there.'

\section{Sensationalism and fear-mongering}

Such excitement is nonetheless tempered with a scare-mongering tone. Jim Al-Khalili regularly points to the fundamental dangerous nature of atom science, first by showing the presence of the nuclear constabulary on the premises. He thus bluntly states at the outset that "within its walls, its material could devastate life on this island and beyond." Along the documentary, the lexical field of danger is used to refer to both the fundamental component - uranium - and the activity through a metonymic process described as "deadly" and "dangerous" in several instances. Uranium is rarely named explicitly throughout the documentary, being more often referred to as "material," "dangerous stuff, "so nasty" and "something so deadly," along many superlative-based phrases such as "the most toxic" or "some of the most dangerous substances on earth." In the other documentary, Bilton hammers on that Sellafield is "Britain's most hazardous nuclear facility" while the situation in Sellafield is described as a "frightening picture."

Both documentaries also share a similar structure with a two-minute expository rundown of the programme, similar to a cinematic preview which features the most thrilling and alluring elements of the show using MTV-style editing, ${ }^{59}$ to lock the viewers' interest and attention. Bilton's documentary opens with a series of edited blunt sentences meant to be anxiety-provoking. For instance, the opening scenes start with: "it's a race against the clock, a ticking clock. Someday that clock is gonna run out and there's going to be a problem," while another voice utters the ominous foretelling: "if there's a fire then, it could generate a plume of radiological waste that could go across Western Europe." Interestingly enough, the viewers discover that the first speaker's unedited words were actually: "without sounding too dramatic, it's a race against the clock." The absence of the first part of the sentence hence reveals the director's purpose was actually the opposite. These previews emphasise the key impact of the editing and formatting work performed here. Tension builds up and escalates through such a dramatization process, notably through the use of stressful sounds, in that the background soundtrack is no mere finishing touch; it stands as particularly instrumental in the process of message creation. ${ }^{60}$ From tambourine-based to shrill 
sounds, the soundtracks of both shows elicit a blend of curiosity, anxiety, and apprehension.

In these two documentaries, the place itself becomes a source of concern and stress, standing as an ominous background presence through the camera work. Buildings are often shot against the sunlight, cutting towering dark shapes against twilight or cloudy skies, thus heightening mystery-like tension. Shots of the dark, murky waters of the storage ponds also heighten an impression of dread as these tanks are said to contain "all sorts of nuclear waste, experimental fuels, highly radioactive isotopes, hazardous irradiated debris and contaminated leftovers." Both directors play with lightning and contrast as well - especially when dealing with dramatic events when Sellafield stood on the verge of a major nuclear catastrophe, with either the 1957 Windscale fire or the 2013 contamination incident. Cookson goes even further than Usborne in staging the 2013 contamination incident as the unfolding of the events is staged again through reenactment. To enhance tension, the account is pared down to a staccato and chronological description of the unfolding of the event using present tenses:

And at 10 to 7 that morning, [the electricity generator] blows. Some of the site nuclear facilities lose power. Part of an emergency safety system also fails [...] ventilation stops working. Radioactive dust is spreading throughout parts of the building [...] it is the worst level of contamination in the plant's history. ${ }^{61}$

In short, Inside Sellafied and Sellafield Nuclear Safety Failings rely on scaremongering and sensationalist cinematic elements to make their case on Sellafield more vivid and catchy to the viewers and provide them with critical exposure based on documented hindsight.

\section{Drama as a balancing act: revived fascination}

41 Yet, in the process, both directors cannot escape emphasising the exceptional and impressive character of the Sellafield site. Through alternatively high-angle and lowangle shots, the sheer gigantic scale of the facilities and machinery is brought to fore. Human presence is either conspicuously absent or limited to the background, utterly belittled by the behemoth buildings, cooling pools, storage silos, or the robotic arms manipulating highly-dangerous underwater materials kept in the legacy tanks. The following screen-capture shows Al-Khalili dwarfed by the massive core wall of one of Sellafield decommissioned reactors: 


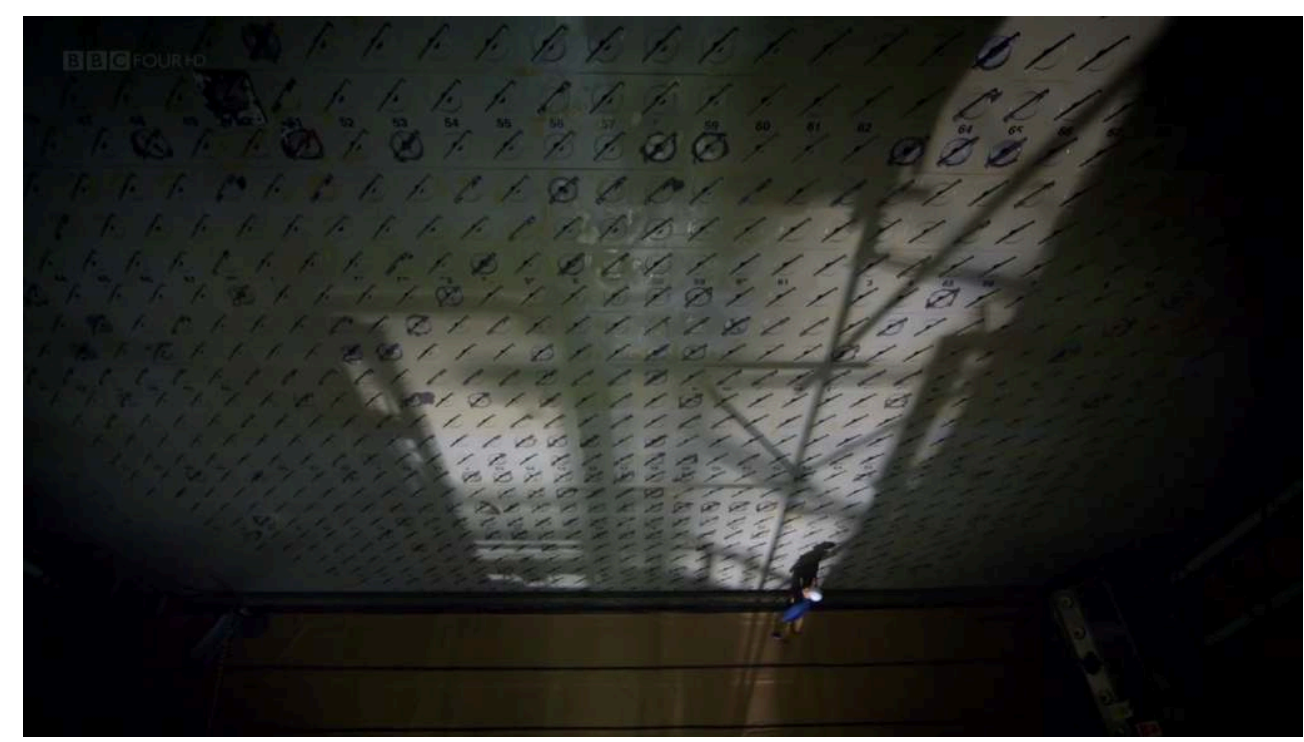

Doc 3. Al-Khalili standing in front of reactor core in Calder Hall, Inside Sellafield (13:41).

42 As Jim Al-Khalili looks up the towering wall of the Calder Hall core, his human height serves as a humbling yet compelling yardstick of the incredible stature of the core which is "twenty meters high, weighing over 2,000 tons, containing 70,000 uranium rods." Here the ominous soundtrack gives way to a much more epic tone, inducing the sense of admiration for those icons of scientific achievements that had characterised the early years of the nuclear expansion, as revealed by stock footage of the construction of the site in the 1950s.

Yet, the British nuclear venture is not only a hollowed-out story of engineering and technological achievements, it is also storified and depicted as a very epic human adventure. Both documentaries rely heavily on the operatives or scientists, either through interviews or photos, to flesh out the narrative. Jim Al-Khalili's account of the history of Sellafield conjures up a hall of fame, a lionising - almost teleological - story of the scientific heroes who made "harness[ing] the limitless power of the atom" possible. He starts off with Otto Hahn, the physicist who accidently discovered the atom's capacities to split while releasing energy. He then credits Robert Oppenheimer, "the father of the nuclear age," who discovered how to obtain plutonium from the splitting of the uranium atom. Al-Khalili then explores the famous 1957 Windscale fire that broke out in the reactor core, triggering "a blazing inferno" that "no one had even believed possible." ${ }^{2}$ The catastrophic consequences of the fire were that that "hundreds of people could [have died]" ${ }^{63}$ if it were not for one man: John Cockcroft. Described as a "maverick genius," Cockcroft is depicted as the saviour figure who prevented the fire from releasing radioactive fumes into the Cumbrian atmosphere on "a whim," ${ }^{64}$ namely by having filters built in the plant's chimney stacks. From a different standpoint, Bilton also extolls the bravery of those involved in the life of Sellafield. Albeit focussing not on the scientists but on the whistleblowing operatives, he supports those brave enough to speak up and denounce the safety issues of the site. One whistle-blower's intervention is dramatized through the use of a blackened silhouette whose words are uttered by an actor.

In a word, both documentaries offer a vast repertoire of exciting devices to penetrate these highly-protected facilities, coupled with expectations, and ultimately fear and admiration. The key driving role of constructing this emotion-inducing content 
through staging, editing, shooting and sound work endows these two documentaries with a fundamental sensationalist dimension - elements quite commonly found in reality TV shows. Despite their truth-seeking aims, the two directors indulge in producing a "creative interpretation of reality" 65 wich entails a very personalised experience for the viewers. The trivialising agenda through popularisation is muted into a distancing process based on awe, meaning a mixture of fear and admiration what could also be called a new form of aesthetic scientific sublime. As such, the scientific truth or hard reality is converted into a more a dramatized form of reality through theatrics and infotainment techniques.

\section{From "veritable truth" to "dramatized truth." the functions of the information-entertainment nexus}

Entertaining is thus deeply embedded in the process of explaining and popularising. The two documentaries under analysis feature traditional characteristics of infotainment based on sensationalist, personalised, and incident-based gripping content. Yet, such dramatization techniques in documentaries have garnered criticism. Documentary-maker Adam Curtis described the use of these "lurid" communication tools and of "the art of emotional storytelling," as "trash techniques." ${ }^{66}$ Scholars similarly argued that the use of infotainment in TV programming is symptomatic of the lowering of journalistic standards and a further step towards their tabloidization. ${ }^{67}$ The two documentaries studied have not escaped criticism either. The nuclear industry discarded the content of the Panorama programme as "sensationalist TV," feeding on "evidence from disgruntled former employees." ${ }^{68}$ Inside Sellafield has similarly been criticised for seeking "to manufacture consent through spectacle." ${ }^{69}$ Many commentators also argued that the use of emotions and entertainment end up undermining the activist dynamic and merely follow the "politics of distraction shifting the public's attention from the essential to the superficial." Curtis also claimed that "if you report things emotionally, it immediately depoliticises them." 70

We contend quite the opposite. This normative and critical interpretation fails to consider documentaries as windows of opportunity to spur discussions and debates over critical and moral public issues. In that sense, infotainment helps re-politicise these questions and works towards fulfilling its original democratic intent, instead of allegedly doing the reverse.

\section{The impact of the Ecological Age: Ecological Infotainment}

By their essential contextual relevance and their socio-political significance, both documentaries offer a forceful mirror of their zeitgeist. By focussing on Sellafied and not on the sites earmarked for the future new nuclear power stations, the two documentaries use the widespread environmental discourses of pollution risks, waste management, and reprocessing as analytical lenses. Infotainment techniques have thus helped code this content along the recent surge in interest in environmental challenges and sustainability, what is known today as the ecological age. ${ }^{71}$ Both documentaries devote much attention to the question of time and of legacy through dramatized shortcuts. By identifying cause-consequence relations between the past, the present, and the future, these documentaries nonetheless draw a very linear timeline. Beside 
revealing a deep-rooted concern for the notions of legacy and impact, this linear vision also points to how tackling environmental risks undoubtedly remains essential in addressing the nuclear agenda.

Since nuclear-induced environmental risks remain fundamentally socially and politically construed, elements of entertainment partake in shaping the viewers' perception of the full scope of the nuclear debates since it goes much further than merely guaranteeing energy supply in the face of the energy transition away from fossil fuels. Behind the question of legacy, it is the whole contemporary pro-nuclear narrative that is being implicitly delineated, given that nuclear power's advocates have relied on its low-carbon credentials to defend the nuclear programme. Yet and interestingly enough, the two documentaries studied give the climate change threat a wide berth, as opposed to one of their American counterparts, Pandora's Promise. Released in 2013, this documentary more openly props its own strategy on "forg[ing] a new political imagery that replaces the apocalyptic image of nuclear fallout with that of catastrophic climate change."72 In short, the critical impact of the context on the framing dynamics of these documentaries contributes to what we could call "ecological infotainment," a form of infotainment deeply embedded in the current hegemonic ecological discourses.

\section{What do these infotainment-style techniques reveal about the relationship between science and the public?}

This use of a sensationalist, emotion-based and now context-based approach helps go beyond standard popularisation and reveals two elements regarding the relationship between science and the general public over the question of science literacy. Firstly, AlKhalili's interest seems to be restoring trust between the general public and scientists as sources of reliable truth, a link that had been eroded and almost severed by the numerous controversies which plagued the nuclear industry and dented its reputation during the 1980s and 1990s. ${ }^{73} \mathrm{Al}-\mathrm{Khalili}$ acknowledges and repents upon the industry's previous failures and mistakes, which are understood as by-products of the industry's early hubris and "complacency." Conversely, the concept of the "learning curve" is repeated on several occasions to fight against the rising age of disinformation. Here the Panorama programme stands clear of top-down popularising which construes "science as a body of pre-established facts which are communicated to a passive public." "74

Nonetheless, Al-Khalali still contends that "many people have a knee-jerk fear of anything nuclear and certainly anything associated with radiation. But it is often an irrational fear built upon too flimsy a grasp of the science." $75 \mathrm{He}$ argues scientists have to overcome public hostility towards nuclear power:

In France, which has more nuclear plants, it's not such a big deal. Here, 'not in my back yard' issues confront any government - it's hard enough to extend Heathrow or Gatwick. People think that it's like The Simpsons, that they're pouring barrels of nuclear waste into a pond. ${ }^{76}$

In that sense, he remains faithful to the dynamic that has underpinned public science policy for the past 30 years. Inside Sellafield still conveys the orthodox idea that the public's vision of nuclear power remains strongly informed by irrational fears and superstition. ${ }^{77}$ It reflects the enduring pattern of the "public understanding of science" (PUS), which has argued that people tend to reject nuclear power because they don't 
understand it. ${ }^{78}$ The PUS movement gained momentum with the Bodmer Report published in $1985 .{ }^{79}$ Since then, it has attracted intense political and academic scrutiny, especially in public policy and science and technology studies (STS). ${ }^{80}$ Restoring trust between the public and scientists has also been part of the PUS agenda since the 2000s. ${ }^{81}$ The PUS movement has no doubt impacted science journalism by further heightening the need to engage with the public and further their understanding of scientific endeavours. In 1998 Gregory and Miller underlined that "in the last decade or so, scientists have been delivered a new commandment from the high: thou shalt communicate", and that popular media remained a key vehicle to influence public's science literacy ${ }^{82}$ In another instance, Al-Khalili insists that the mission he embraced was to push "back the tides of scientific ignorance with an empathetic understanding of the needs and competences of the audience. ${ }^{{ }^{83}}$ His words therefore reveals his belief that physicists playing the part of pragmatic missionaries for science remains a traditional norm in popularisation..$^{84}$

Such a lingering presence of the PUS rationale in this documentary therefore questions the heralded shift towards the public engagement paradigm, which has become rather popular in STS academic circles over the last decade. ${ }^{85} \mathrm{Based}$ on recent studies on the participatory and dialogic turn in science governance, it has indeed been argued that the public should no longer be considered as mere recipients of science communication, but should be reframed as active participants in science communication and production. Yet, the lack of multiple or alternative interpretations channelled through these documentaries tend to suggest that a top-down approach remains strong beneath this veneer of transparency and democratisation. In the documentaries studied, the shift from PUS to the public engagement with science remains more rhetorical than genuine. ${ }^{86}$ Brian Wynne has reached similar conclusions, contending that "new deficit models of the public" have been "reinvent[ed] and reincarnat[ed] in some new form." 87

Secondly, the hybrid quality of the science documentaries studied indicates the fundamental need to adapt to an audience, whose attention-span has become increasingly limited and easily prey to cognitive dissonance. ${ }^{88}$ The idea seems once again to engage in a missionary campaign to reach more new converts. This endeavour is particularly relevant given the "easier access not only to cheaper and more userfriendly technology but also to new distribution platforms." ${ }^{89}$ Diversification and adaptation stand as a condition to survival in an increasingly polyphonic media ecosystem. Bilton thus resorts to using illegal videos of inside the Sellafield legacy ponds, retrieved from YouTube, thus acknowledging the democratic and knowledgecreating role that 'Netizens' can also play in denouncing scientific misdemeanours. ${ }^{90}$ As Wineburg and al. stated, film and television have become social loci of historical discussions in households and a major source of individual knowledge. ${ }^{91} \mathrm{Al}$-Khalili's interest seems to lie in broadening up his audience-base, which so far remained mostly left-leaning white mature male (YouGov). ${ }^{92}$ The use of infotainment techniques therefore also aims at generating wider public interest by bridging the gap between generations, between educational and civic training. 


\section{Conclusions}

54 This study aimed at confirming that recent $\mathrm{BBC}$ science material did not escape the rising cloud of entertainment devices in popularising programmes. As Rehman argued, "infotainment science journalism [has become] the dominant form of science writing, because the portrayal of science as an exciting adventure with great promise and few uncertainties is bound to garner a large" audience. ${ }^{93}$ These two documentaries have revealed their expanding hybrid quality by blurring the lines between reality and fiction, spectacular and aesthetic purposes, entertaining and informing (infotainment), and finally between informing and educating (edutainment). Entertainment devices have become more deeply intertwined within popularising ingredients to such an extent that it has become difficult to distinguish the two. It may indicate that science infotainment broadcasting is turning into a separate television subculture, just as infotainment-style science journalism has grown increasingly distinct from science journalism..$^{94}$

55 Yet, when put back into historical perspective, Inside Sellafield and Sellafied's Nuclear Safety Failings can be considered as both innovative and orthodox: on the one hand, they may represent a new development in British television tradition. When looking at traditional British documentaries, scholars used to describe them as fact-rich, realitybased "discourses of sobriety," often opposing them to what they identified as their more dramatized American counterparts. ${ }^{95}$ Yet, the use of elements of entertainment seemingly altered this distinction as this alleged gap between American and British documentary traditions has been closing. Moreover, directors Usborne and Cookson engage in a more critical investigation of the Sellafield site, thus attempting to transcend the divide between the traditionally pro-nuclear narratives of the documentaries made in the 1950s-60s and the more critical turn of the 1970s-90s.

Conversely, this new trend did not radically alter the conventional aim of the British documentary tradition, namely to popularise science and establish a hierarchical order between science and the public. The infotainment-based approach blended in with and actually reinforced the traditional "alchemy of languages" which has characterised traditional science documentaries, despite calls to further 'democratise' access to the world of nuclear science. Despite their controversial premises, they still offer narratives, which restrict the emergence of competing or alternative interpretations or opinion, embodying what Rehman has denounced as "non-critical science journalism. ${ }^{96}$

By conveying a message fraught with fear and admiration, a feeling of awe for Britain's nuclear venture, these two documentaries still mix the vernacular and scientific lexicons to endow them with a somewhat poetic load. In that sense, Inside Sellafield and Sellafield's Nuclear Safety Failings comply with earlier British nuclear narratives, which aimed at presenting science and scientists as agents of national pride and modern heroes. These documentaries, supposedly both informative and engaging, theoretically acted as "portal devices," bridges to encourage the audience's engagement with controversial topical issues such as nuclear power. Yet, just as Gigante concluded in her recent analysis of the external visual rhetoric of science: "[instead of] situating science in society, making science a part of civic matters rather than above or separate from them, the portal images [...] serve to valorise the scientific enterprise, to set it in a realm above society and civic matters. ${ }^{.97}$ Eventually these two infotainment-style 
documentaries simultaneously popularise and mystify science. Whether these documentaries act as more progressist embodiments of the public engagement paradigm remains fairly questionable.

Finally, it also turns out that - albeit criticised by scholars and practitioners alike - the infotainment dynamics identified in science documentaries are symptomatic of the era in which they are embedded. For instance, they align with three factors: the rise of ecological consciousness, the growing distrust of expertise and state-run narratives and the fragmentation of news outlets on digital platforms. One last question arises: has infotainment outweighed popularisation due to this changing context? We believe that entertainment here still services popularisation. We interpret infotainment not just as a set of techniques but also as a modernising 'exposure parameter,' which seeks to reveal what is hidden and participate in constructing a more nuanced and evidencebased political message. If nuclear science has been transmuted into an epic venture again, its shape is made to adapt to the ecological age and its concerns.

\section{BIBLIOGRAPHY}

Al-Khalili, Jim. "What Goes on with Nuclear Power.” The Telegraph, August 10, 2015.

"What goes on in our nuclear industry?" The Telegraph, August 12, 2015.

Angler, Martin. Science Journalism: An Introduction. London: Routledge, 2017.

Anthony, Andrew. "Adam Curtis: Cult Film-Maker with an Eye for the Unsettling." The Guardian, January 4, 2015.

Bauer, Martin and Jane Gregory. "From Journalism to Corporate Communication in Post-War Britain." In Science, Journalism and Society: Science Communication Between News and Public Relations, edited by Michael Bauer and Massimiano Bucchi, 33-52. London: Routledge, 2007.

Baum, Matthew. "Soft News and Political Knowledge: Evidence of Absence or Absence of Evidence?" Political Communication 20, (October 2010): 173-190.

Benvenido, Léon and Michael Bourk. Communicating Science and Technology through Online Videos: Researching a New Media Phenomenon. Abingdon: Routledge, 2018.

Bodmer, William. The Public Understanding of Science. London: Royal Society, 1985.

Boltz, Marylin. "The Cognitive Processing of Film and Musical Soundtracks." Memory and Cognition 32, (2004): 1194-1205.

Boon, Timothy. "The Televising of Science is a Process of Television: Establishing Horizon, 1962-67." Journal for the History of Science 48, no. 1 (2015): 87-121.

Bradford, Peter. "Nuclear Renaissance was just a fairy tale." The Guardian, July 11, 2013.

Bourdieu, Pierre. Sur la télévision. Paris : Liber-Raisons d'Agir, 1996.

Charaudeau, Patrick. La médiatisation de la science. Brussels : De Boeck, 2008.

Coppola, Al. The Theater of Experiment. Oxford: Oxford University Press, 2016. 
Corner, John. The Art of Record: A Critical Introduction to Documentary. Manchester: Manchester University Press, 1996.

Dancyger, Ken. The Technique of Film and Video Editing: History, Theory, and Practice. Abingdon: Focal Press, 2007.

Davies, Gail. "Science, Observation and Entertainment: Competing Visions of Postwar British Natural History Television, 1946-1967.” Ecumene 7, no. 4 (2000).

Delgado, Ana et al. "Public Engagement Coming of Age: From Theory to Practice in STS Encounters with Nanotechnology.” Public Understanding of Science 20, no. 6 (2011): 826-845.

Deprez, Camille and Judith Perine eds. Post-1990 Documentary: Reconfiguring Independence. Edinburgh: Edinburgh University Press, 2015.

Edgar, David. “Theater of Fact: A Dramatist's Viewpoint." In Why Docudrama? Fact-Fiction on Film and TV, edited by Alan Rosenthal, 174-188. Edwardsville: Southern Illinois University Press, 1999.

Evan, Susannah. "Shark Week and the Rise of Infotainment in Science Documentaries." Communication Research Reports 21, no. 3 (2015): 265-271.

Fahy, Declan. The New Celebrity Scientists: Out of the Lab into the Limelight. London: Rowman \& Littlefield, 2015.

Faina, Joseph. "Public Journalism is a Joke: The Case of Jon Stewart and Stephen Colbert." Journalism 14, no. 4, (June 2012): 541-555.

Felt, Ulrike. "Why Should the Public 'Understand' Science? a Historical Perspective on Aspects of the Public Understanding of Science." In Between Understanding and Trust: The Public, Science and Technology, edited by Meinolf Dierkes and Claudia Von Grote. London: Routledge, 2000.

Fournier, George. "British Docudrama." InMedia, The French Journal of Media Studies 3 (2013).

Franklin, Bob. Newszak and News Media. London: Lesley Riddle, 1997.

Friedman, Sharon ed. Communicating Uncertainty: Media Coverage of New and Controversial Science. Mahwah: Lawrence Erlbaum Associates, 2009.

Gigante, Maria. Introducing Science through Images: Cases of Visual Popularisation. Columbia: University of South Carolina Press, 2018.

Godmilow, Jill and Ann-Louise Shapiro. "How Real is the Reality in Documentary Film?" History and Theory 36, no 4 (December 1997): 80-101.

Gregory, Jane and Steve Miller. Science in Public: Communication, Culture, and Credibility. Cambridge: Perseus Books, 1998.

Greenwood, Carl. "Britain's Nuclear Secrets: Inside Sellafield will Show Viewers the Reality of Atomic Power." Mirror, July 23, 2015.

Gouyon, Jean-Baptiste. “Science and Film-Making." Public Understanding of Science 1-14 (2015): 17-30.

Hartwell, Laura. "Exploring English for the Nuclear Industry in Biographical

Films: Oppenheimer and Silkwood." Cahiers de l'APLIUT 30, no. 2 (2011): 96-111.

Henderson, Eugene. "New BBC Panorama Documentary Broadcast Nuclear Plant Safety Failures." The Express, September 4, 2016.

Hogg, Jonathan. British Nuclear Culture. London: Bloomsbury, 2016. 
Holton, Gerald. Einstein, History and other Passions: The Rebellion against Science at the End of the Twentieth Century. New York: AIP Press, 1995.

Irwin, Alan and Brian Wynne eds. Misunderstanding Science? The Public Reconstruction of Science and Technology. Cambridge: Cambridge University Press, 1996.

Jodelka, Filipa. "Britain's Nuclear Secrets: Inside Sellafield - a very British Fission of the Past." The Guardian, August 10, 2015.

Johnson, Nuala. Culture and Society: Critical Essays on Human Geography. London: Routledge, 2008.

Johnson, Robert. Romancing the Atom: Nuclear Infatuation from the Radium Girls to Fukushima. Santa Barbara: Praeger, 2012.

Kishan Thussu, Daya. News as Entertainment: The Rise of Global Infotainment. London: Sage, 2007.

Laigle, Guillaume. "Le Trou Noir de Synthèse, un Divertissement Educatif." In L'Appel du

Divertissement - Télévision n4, edited by François Jost, 85-104. Paris : CNRS Editions, 2013.

Lash, Scott, Bronislaw Szerszynski, and Brian Wynne eds. Risk, Environment and Modernity: Towards a New Ecology. Oxford: Sage, 1996.

Latour, Bruno. Science in Action: How to Follow Scientists and Engineers through Society. Cambridge: Cambridge University Press, 1996.

Lees, Nicola. Greenlit: Developing Factual TV ideas from Concept to Pitch: The Professional Guide to Pitching Factual Shows. London: A\&C Black, 2010.

Livingstone, David. "The Spaces of Knowledge: Contributions towards a Historical Geography of Science." Environment and planning: Society and space 13 (1995): 5-34.

Locke, Simon. "The Public Understanding of Science - a Rhetorical Invention." Science, Technology and Human Values 27 (2002): 87-111.

Mariono, Antigone. “Britain's Nuclear Secrets: Inside Sellafield.” Europhysics News 48, no. 5-6 (2017). Url: https://www.europhysicsnews.org/articles/epn/abs/2017/05/epn2017485-6p21/ epn2017485-6p21.html <accessed on 25 March 2018>

Melville, Casper. "Facing the Future: an Interview with Jim Al-Khalili." New Humanist, March 7, 2013.

Nichols, Bill. Speaking Truths with Film: Evidence, Ethics, Politics in Documentary. Oakland: University of California Press, 2016.

Paget, Derek. "Making Mischief: Peter Kominsky, Stephen Frears and British Television Docudrama." Journal of British Cinema and Television 10, no. 1 (January 2013): 171-186.

Patterson, Laura. “Jim Al-Khalili Interview.” Young Scientists Journal, November 20, 2016.

Philipps, Louise. The Promise of Dialogue: The Dialogical Turn in the Production and Communication of Knowledge. Amsterdam: John Benjamins Publishing Company, 2011.

Philipps, Louise J. ed. Citizen Voices: Performing Public Participation in Science and Environment. Bristol: Intellect, 2012.

Raeside, Julia. "Race for the New World's First Atomic Bomb: A Thousand Days of Fear Review - a 'Coldly Scientific Account."' The Guardian, August 11, 2015.

Rehman, Jalees. “The Need for Critical Science Journalism.” The Guardian, May 16, 2013.

Rosenstone, Robert. History on Film/Film on History. Abingdon: Routledge, 2012. 
Sagan, Carl. The Demon-Haunted World: Science as a Candle in the Dark. New York: Ballantine Books, 1997.

Secretary of State for Culture, Media and Sport. Broadcasting: Royal Charter for the Continuance of the British Broadcasting Corporation. London: HMSO, 2016.

Shapin, Steve. "Why the Public ought to Understand Science-in-the-Making." Public Understanding of Science 1, no. 1 (January 1992): 27-30.

Shaw, Tony. "The BBC, the State and Cold War Culture: The Case of Television's The War Game." The English Historical Review 494 (2006): 1351-84.

Shinn, Terry and Richard Whitley eds. Expository Science: Forms and Functions of Popularisation. Dordrecht: Reidel Publishing Company, 1985.

Smith, Nathan and Jenny Rock. "Documentary as a Statement: Defining Old Genre in a new Age." Journal of Media Practice 15, no. 1 (2014): 58-62.

Sparks, Colin. “The Panic over Tabloid News.” In Tabloid Tales: Global Debates over Media Standards, edited by Colin Sparks and John Tulloch, 1-38. New York: Rowman and Littlefield, 2000.

Street, John. "Prime time Politics: Popular Culture Politicians in the UK." Journal of the European Institute for Communication and Culture 7, no. 2 (2000): 75-89.

Thrift, Nigel and David Livingstone. "The Geography of Truth." Environment and planning: Society and space 13 (1995): 1-4.

Torrey, Volta, Irving J. Gitlin, Louis M. Heil and Joe Musial. “Communication Mediums Explain and Illustrate Nuclear Energy." The Journal of Educational Sociology 22, no. 5 (January 1949): 324-336.

Van Munster, Rens and Casper Sylvest, "Pro-Nuclear Environmentalism Should We Learn to Stop Worrying and Love Nuclear Energy?” Technology and Culture 56, no. 4 (2015): 789-811.

Weiskel, Timothy. "From Sidekick to Sideshow - Celebrity, Entertainment, and the Politics of Distraction." American Behavioral Scientist 49, no. 3 (2005): 393-409.

Williams, Linda. "Mirrors without Memories: Truth, History and the New Documentary." In New Challenges for Documentary, edited by Alan Rosenthal and John Corner, 59-75. Manchester: Manchester University Press, 2005.

Wineburg, Sam et al. "Common Belief and the Cultural Curriculum: An Intergenerational Study of Historical Consciousness." American Education Research Journal 44, no. 1 (2007): 40-76.

Winston, Brian. Claiming the Real. Documentary: Grierson and Beyond. London: Palgrave Macmillan, 2008.

Winston, Brian. "The documentary film as scientific inscription.” In Theorizing documentary, edited by Michael Renov, 37-58. London: Routledge, 1993.

Wynne, Brian. "Public Engagement as Means of Restoring Trust in Science? Hitting the Notes, but Missing the Music." Community Genetics 9, no. 3 (2006): 211-220.

\section{ENDNOTES}

1. Bill Nichols, Speaking Truths with Film: Evidence, Ethics, Politics in Documentary (Oakland: University of California Press, 2016), 14. 
2. Tony Shaw, "The BBC, the State and Cold War Culture: The Case of Television's The War Game," The English Historical Review 494, (2006): 1365.

3. Jean-Baptiste Gouyon, "Science and Film-Making," Public Understanding of Science 1-14, (2015): 19.

4. Filipa Jodelka, "Britain's Nuclear Secrets: Inside Sellafield - a very British Fission of the Past," The Guardian, August 10, 2015.

5. Sharon Friedman (ed.), Communicating Uncertainty: Media Coverage of New and Controversial Science (Mahwah: Lawrence Erlbaum Associates, 2009), 3-4.

6. John Street, "Prime time Politics: Popular Culture Politicians in the UK," Journal of the European Institute for Communication and Culture 7 (2), (2000): 75-89.

7. Pierre Bourdieu, Sur la télévision (Paris : Liber-Raisons d'Agir, 1996), 31.

Bob Franklin, Newszak and News Media (London: Lesley Riddle, 1997).

8. Daya Kishan Thussu, News as Entertainment: The Rise of Global Infotainment (London: Sage, 2007).

9. Kishan Thussu, News as Entertainment: The Rise of Global Infotainment, 3.

10. Patrick Charaudeau, La médiatisation de la science (Brussels : De Boeck, 2008),7-10.

11. Joseph Faina, "Public Journalism is a Joke: The Case of Jon Stewart and Stephen Colbert," Journalism 14 (4), (June 2012): 541-555.

12. Susannah Evan, "Shark Week and the Rise of Infotainment in Science Documentaries," Communication Research Reports 21 (3), (2015).

13. Tim Usborne is a seasoned British documentary-maker on science questions. He directed four science documentaries on quantum physics, electricity or famous scientists between 2007 and 2014.

14. Antigone Mariono, "Britain's Nuclear Secrets: Inside Sellafield," Europhysics News 48 (5-6), (2017). Url: https://www.europhysicsnews.org/articles/epn/abs/2017/05/ epn2017485-6p21/epn2017485-6p21.html <accessed on 25 March 2018>

15. Originally called Windscale, the site hosted a military-ran nuclear pile, later converted into the first commercial nuclear power reactor, Calder Hall, connected to the national grid in 1957. The complex's activities later on diversified into nuclear fuel cycle industry with several storage facilities for used radioactive components, and a reprocessing plant, THORP, opened in 1994. The site also features decommissioning facilities.

16. Peter Bradford, "Nuclear Renaissance was just a fairy tale," The Guardian, July 11, 2013.

17. In 2008 the UK government opened the British markets to private nuclear operators to engage in the nuclear programme. Eight sites were first earmarked as potential locations for the new generation of nuclear plants. In 2009, Three major consortia revealed their interest: Horizon (Wylfa, Oldbury), NuGen (Sellafield), and EDF-Centrica (Hinkley Point C, Sizewell). By 2013, Horizon, $\mathrm{NuGen}$ and Centrica had pulled out of the programme, thus jeopardising the future of the nuclear programme in Britain.

18. Nichols, Speaking Truths with Film: Evidence, Ethics, Politics in Documentary, 13.

19. Gouyon, "Science and Film-Making," 19.

20. Martin Bauer and Jane Gregory, "From Journalism to Corporate Communication in Post-War Britain," in Science, Journalism and Society: Science Communication Between News and Public Relations, eds. Michael Bauer and Massimiano Bucchi (London: Routledge, 2007), 33-52.

21. Jane Gregory and Steve Miller, Science in Public: Communication, Culture, and Credibility (Cambridge: Perseus Books, 1998), 44.

22. Ibid., 45.

23. Frank M. Turner, "Public Science in Britain 1880-1919", Isis 71 (4), (1980): 589-590.

24. Steve Shapin, "Why the Public ought to Understand Science-in-the-Making," Public Understanding of Science 1 (1), (January 1992): 27-30. 
25. George Fournier, "British Docudrama," InMedia The French Journal of Media Studies 3, (2013).

26. Léon Benvenido and Michael Bourk, Communicating Science and Technology through Online Videos: Researching a New Media Phenomenon (Abingdon: Routledge, 2018).

27. Secretary of State for Culture, Media and Sport, Broadcasting: Royal Charter for the Continuance of the British Broadcasting Corporation (London: HMSO, 2016), 5.

28. Shaw, "The BBC, the State and Cold War Culture: The Case of Television's The War Game," 1365.

29. Statista.com. Url: https://www.statista.com/statistics/269983/leading-tvbroadcasters-in-the-uk-by-audience-share/ <accessed on 30 May 2018>

30. Declan Fahy, The New Celebrity Scientists: Out of the Lab into the Limelight (London: Rowman \& Littlefield, 2015), 3.

31. Laura Patterson, “Jim Al-Khalili Interview," Young Scientists Journal, November 20, 2016.

32. Fahy, The New Celebrity Scientists: Out of the Lab into the Limelight, 2.

33. Casper Melville, "Facing the Future: an Interview with Jim Al-Khalili," New Humanist, 7 March 2013.

34. Julia Raeside, "Race for the New World's First Atomic Bomb: A Thousand Days of Fear Review - a “Coldly Scientific Account," The Guardian, 11 August 2015.

35. David Edgar, “Theater of Fact: A Dramatist's Viewpoint." In Why Docudrama? Fact-Fiction on Film and TV, ed. Alan Rosenthal (Edwarsville: Southern Illinois University Press, 1999), 174-188.

36. David Livingstone, “The Spaces of Knowledge: Contributions towards a Historical Geography of Science," Environment and planning: Society and space 13, (1995): 5-34.

Nigel Thrift and David Livingstone, "The Geography of Truth," Environment and planning: Society and space 13, (1995): 2.

37. Gail Davies, "Science, Observation and Entertainment: Competing Visions of Postwar British Natural History Television, 1946-1967," Ecumene 7 (4), (2000).

38. Thrift and Livingstone "The Geography of Truth," 2.

39. Filipa Jodelka, "Britain's Nuclear Secrets: Inside Sellafield - a very British fission of the past."

40. Laura M. Hartwell, "Exploring English for the Nuclear Industry in Biographical Films: Oppenheimer and Silkwood," Cahiers de l'APLIUT 30 (2), (2011): 96-111.

41. Al Coppola, The Theater of Experiment (Oxford: Oxford University Press, 2016).

42. Tim Usborne, "How we split the atom for a television programme," BBC, https:// www.bbc.co.uk/programmes/articles/1fJQlwy1KY775HflGHFvxWK/how-we-split-the-atom-for-atelevision-programme < accessed June 2018>

43. Guillaume Laigle, "Le Trou Noir de Synthèse, un Divertissement Educatif," in L'Appel du Divertissement - Télévision $n^{\circ} 4$, ed. François Jost (Paris : CNRS Editions, 2013), 85-104.

44. Martin Angler, Science Journalism: An Introduction (London: Routledge, 2017), 9-10.

45. Jalees Rehman, “The Need for Critical Science Journalism," The Guardian, May 16, 2013.

46. John Corner, The Art of Record: A Critical Introduction to Documentary (Manchester: Manchester University Press, 1996), 68.

Brian Winston, Claiming the Real. Documentary: Grierson and Beyond (London: Palgrave Macmillan, 2008).

Linda Williams, "Mirrors without Memories: Truth, History and the New Documentary," in New Challenges for Documentary, eds. Alan Rosenthal and John Corner (Manchester: Manchester University Press, 2005), 59-75.

47. Robert Rosenstone, History on Film/Film on History (Abingdon: Routledge, 2012), 171. 
48. Here the term "controversial" characterises polarising and debated issues, which imply two opposing standpoints, which are both legitimate, thus triggering public disagreements (OED).

49. Sharon (ed.), Communicating Uncertainty: Media Coverage of New and Controversial Science, 4.

50. Jim Al-Khalili, "What goes on in our nuclear industry?," The Telegraph, August 12, 2015.

51. Nicola Lees, Greenlit: Developing Factual TV ideas from Concept to Pitch: The Professional Guide to Pitching Factual Shows (London: A\&C Black, 2010), 130.

52. Fournier, "British Docudrama."

53. Nathan Smith and Jenny Rock, "Documentary as a Statement: Defining Old Genre in a new Age," Journal of Media Practice 15 (1), (2014): 58.

54. Robert Johnson, Romancing the Atom: Nuclear Infatuation from the Radium Girls to Fukushima (Santa Barbara: Praeger, 2012), 1.

55. Jonathan Hogg, British Nuclear Culture (London: Bloomsbury, 2016), 17.

56. Nichols, Speaking Truths with Film: Evidence, Ethics, Politics in Documentary, 2.

57. Carl Greenwood, "Britain's Nuclear Secrets: Inside Sellafield will Show Viewers the Reality of Atomic Power," Mirror, July 23, 2015.

58. Bruno Latour, Science in Action: How to Follow Scientists and Engineers through Society (Cambridge: Cambridge University Press, 1996).

Brian Winston, "The documentary film as scientific inscription," in Theorizing documentary, Michael Renov, ed, (London: Routledge, 1993), 43.

59. The MTV-style refers to editing strategies and stylistic techniques, which disrupt the linear arc of the story line to put more emphasis on feelings and moods through the use of evocative visual stimuli and music. The intent is to depart from conventional approaches to time, space, and plot. The term MTV (Music TV) underlines the influence of TV commercials or short music videos on traditional film-making.

See: Ken Dancyger, The Technique of Film and Video Editing: History, Theory, and Practice (Abingdon: Focal Press, 2007), 184-198.

60. Marylin Boltz, "The Cognitive Processing of Film and Musical Soundtracks," Memory and Cognition 32, (2004): 1194-1205.

61. Richard Cookson, Sellafield Nuclear Safety Failings (BBC1 Panorama, 2016), 13:05-13-46.

62. Tim Usborne, Britain's Nuclear Secrets: Inside Sellafield (BBC 4, 2015), 26:15-27:00.

63. Ibid., 28: 10 .

64. Ibid., 30:07.

65. Terry Shinn and Richard Whitley, eds, Expository Science: Forms and Functions of Popularisation (Dordrecht: Reidel Publishing Company, 1985), 10.

66. Andrew Anthony, "Adam Curtis: Cult Film-Maker with an Eye for the Unsettling," The Guardian, January 4, 2015. Adam Curtis is one of the most renowned British documentary directors.

67. Colin Sparks, "The Panic over Tabloid News," in Tabloid Tales: Global Debates over Media Standards, eds. Colin Sparks and John Tulloch (New York: Rowman and Littlefield, 2000).

68. Eugene Henderson, "New BBC Panorama Documentary Broadcast Nuclear Plant Safety Failures," The Express, 4 September 2016.

69. Timothy Weiskel, "From Sidekick to Sideshow - Celebrity, Entertainment, and the Politics of Distraction," American Behavioral Scientist 49 (3) (2005): 396.

70. Anthony, "Adam Curtis: Cult Film-Maker with an Eye for the Unsettling."

71. Scott Lash, Bronislaw Szerszynski, and Brian Wynne, eds, Risk, Environment and Modernity: Towards a New Ecology (Oxford: Sage, 1996). 
72. Rens van Munster and Casper Sylvest, "Pro-Nuclear Environmentalism Should We Learn to Stop Worrying and Love Nuclear Energy?" Technology and Culture 56 (4), (2015): 791.

73. Ulrike Felt, “Why Should the Public 'Understand' Science? a Historical Perspective on Aspects of the Public Understanding of Science," in Between Understanding and Trust: The Public, Science and Technology, ed Dierkes, Meinolf and Claudia Von Grote (London: Routledge, 2000).

74. Nuala Johnson, Culture and Society: Critical Essays on Human Geography (London: Routledge, 2008).

75. Jim Al-Khalili, "What Goes on with Nuclear Power," The Telegraph, August 10, 2015.

76. “Inside Sellafield: Britain's Notorious Nuclear Power Plant," Radiotimes, August 10, 2015.

77. Carl Sagan, The Demon-Haunted World: Science as a Candle in the Dark (New York: Ballantine Books, 1997).

78. Gerald Holton, Einstein, History and other Passions: The Rebellion against Science at the End of the Twentieth Century (New York: AIP Press, 1995).

79. William Bodmer, The Public Understanding of Science (London: Royal Society, 1985).

80. Alan Irwin and Brian Wynne (eds.), Misunderstanding Science? The Public Reconstruction of Science and Technology (Cambridge: Cambridge University Press, 1996).

See also the academic journal Public Understanding of Science created in 1992.

81. Brian Wynne, "Public Engagement as Means of Restoring Trust in Science? Hitting the Notes, but Missing the Music," Community Genetics 9 (3), (2006): 213.

82. Gregory and Miller, Science in Public: Communication, Culture, and Credibility, 35.

83. Laura Patterson, "Jim Al-Khalili Interview."

84. Volta Torrey, Irving J. Gitlin, Louis M. Heil and Joe Musial, "Communication Mediums Explain and Illustrate Nuclear Energy," The Journal of Educational Sociology 22 (5), (January 1949): 324-336.

85. Ana Delgado et al. "Public Engagement Coming of Age: From Theory to Practice in STS Encounters with Nanotechnology," Public Understanding of Science 20 (6), (2011): 826-845.

Louise J. Philipps (eds.), Citizen Voices: Performing Public Participation in Science and Environment (Bristol: Intellect, 2012) 1.

86. Simon Locke, "The Public Understanding of Science - a Rhetorical Invention," Science, Technology and Human Values 27 (2002): 87-111.

Louise J. Philipps, The Promise of Dialogue: The Dialogical Turn in the Production and Communication of Knowledge (Amsterdam: John Benjamins Publishing Company, 2011).

87. Wynne, "Public Engagement as Means of Restoring Trust in Science? Hitting the Notes, but Missing the Music," 213.

88. Matthew Baum, "Soft News and Political Knowledge: Evidence of Absence or Absence of Evidence?" Political Communication 20, (October 2010): 173-190.

89. Camille Deprez and Judith Perine, eds, Post-1990 Documentary: Reconfiguring Independence, (Edinburgh: Edinburgh University Press, 2015), 1.

90. Mick Broderick and Robert Jacobs, "Fukushima and the Shifting Conventions of Documentary: from Cinema and Broadcast to Social Media Netizenship," In Post-1990 Documentary: Reconfiguring Independence, eds. Deprez and Perine, 228.

91. Sam Wineburg et al., "Common Belief and the Cultural Curriculum: an Intergenerational Study of Historical Consciousness," American Education Research Journal 44 (1), (2007): 40-76.

92. Yougov Profiles, Ur: https://yougov.co.uk/opi/browse/Jim_Al_Khalili <accessed 13

May 2018>

93. Rehman, "The Need for Critical Science Journalism." 
94. Timothy Boon, "The Televising of Science is a Process of Television: Establishing Horizon, 1962-67," Journal for the History of Science 48 (1), (2015).

Angler, Science Journalism: An Introduction, 9-10.

95. Jill Godmilow and Ann-Louise Shapiro, "How Real is the Reality in Documentary Film?" History and Theory 36 (4), (December 1997): 87.

Derek Paget, "Making Mischief: Peter Kominsky, Stephen Frears and British Television Docudrama," Journal of British Cinema and Television 10 (1), (January 2013): 171-186.

96. Rehman, "The Need for Critical Science Journalism."

97. Maria Gigante, Introducing Science through Images: Cases of Visual Popularisation (Columbia: University of South Carolina Press, 2018), 3.

\section{ABSTRACTS}

The purpose of this paper is to explore how British documentaries on nuclear power offer insight into the relationship between science information and entertainment, and between science and the public in the new age of environmental concerns and ecological transition. The analysis of two recent $\mathrm{BBC}$ documentaries on this controversial and highly-divisive topic will focus on the impact of elements of entertainment on their popularisation agenda, somehow blending edutainment with infotainment. It will show how dramatization may influence not only the viewers' relation to nuclear science and experts, but also the goals pursued by these documentaries. Ultimately, these sources will help reveal whether informing/educating still prevails over entertainment, thus redefining the face of British science through infotainment in the ecological age.

\section{INDEX}

Keywords: nuclear power/ infotainment/edutainment/documentaries.

\section{AUTHOR}

\section{LUCIE DE CARVALHO}

Lucie de Carvalho is a senior lecturer in British political history at the university of Lille-SHS. Her research focusses on governance and British nuclear and environmental policies (1979-2019). 